\title{
KORUPSI DI INDONESIA
}

\author{
Rifyal Ka'bah' ${ }^{1}$
}

Abstrak

This article explains on corruption phenomenon in many approaches to solve and also here be initiated elaborations regarding the definitions of corruption as the systematic descriptions. Two recent's cases are both tactical funds of General Election Comission (KPU) and Dana Abadi Umat (people's escrow funds) at Department of Religious Affairs. The author suggested that law enforcement is as way out to eliminate through corruption practice in Indonesia. It does embark on law enforcement's thought which recognizes reward and punishment methods on both sides behaviour applied. Alerted also here on the general principle of presume innocence which ought to apply in corruption case's

Kata kunci: korupsi di indonesia, kajian hukum, kasus-kasus, konsep dasar dan solusi

\section{Pendahuluan}

Wartawan terkenal, almarhum Mukhtar Lubis pernah mengatakan pada tahun tujuh puluhan bahwa korupsi telah menjadi budaya bangsa Indonesia. Sebuah pernyataan yang menggelitik dan menyinggung banyak orang, tetapi susah untuk diingkari.

Manusia itu berbudaya, maka hasil kebudayaan manusia melahirkan peradaban yang lebih baik dari masa ke masa. Hal-hal yang dihasilkan oleh peradaban maju antara lain adalah budaya bersih, budaya sehat, budaya rapih, budaya cerdas, budaya santun, budaya anti kekerasan, kejahatan dan ketidak adilan, dan lain-lain. Dengan menyebut korupsi sebagai budaya, apakah berarti bahwa orang Indonesia pada umumnya telah menjadi makhluk rakus, tidak lagi patuh kepada norma agama dan hukum, tidak tahu lagi

1 Penulis adalah Staf Pengajar tidak tetap Program Pascasarjana Ilmu Hukum Fakultas Hukum Universitas Indonesia. dan dosen Hukum Islam di berbagai perguruan tinggi. seperti halnya di Universitas Yarsi Jakarta. UI. Unisba. Universitas Hamka. dan lain-lain. Beliau adalah alumnus IAIN Imam Bonjol Padang (1973). Universitas Al-Azhar Cairo Mesir (1976). dan magister (MA) lulusan Studi Islam di Department of Social Sciences Kairo dan Doktor Ilmu Hukum diraihnya dari Program Pascasarjana UI Jakarta. 
sopan-santun, telah hidup bak binatang buas di hutan balantara yang hanya ingin selamat sendiri?

Budaya sebagai hasil usaha manusia yang sadar selalu dibudayakan dari generasi ke generasi. Pembudayaan tersebut biasanya dilakukan melalui pendidikan formal dan non formal, dari guru ke murid, dari orang tua ke anak-cucu, dari tokoh ke khalayak ramai, dan seterusnya. Bila benar, korupsi telah menjadi budaya bangsa Indonesia, maka berarti pembudayaan korupsi sedang berjalan dalam masyarakat. Untuk menguji kebenaran "teori" Mukhtar Lubis ini memerlukan dukungan data lapangan, dari praktek yang berlaku di tengah masyarakat Indonesia pada waktu ini.

\section{A. Pengertian Korupsi}

Korupsi berasal dari kata corruptus yang berarti perubahan tingkah laku dari baik menjadi buruk (to change from good to bad in morals, manners. or actions); rot, spoil ${ }^{2}$ (rontok, rusak); dan lain-lain. Secara hukum, korupsi adalah "sebuah perbuatan yang dilakukan dengan maksud memberikan keuntungan yang tidak sesuai dengan tugas resmi dan hak orang lain" (an act done with an intent to give some advantage inconsistent with official duty and the right of others). ${ }^{3}$ Pasal 2 ayat (1) UU No. 21 Tahun 1999 tentang Pemberantasan Tindak Pidana Korupsi menyebutkan bahwa orang yang dapat dipidana karena tindak pidana korupsi adalah "Setiap orang yang secara melawan hukum melakukan perbuatan memperkaya diri sendiri atau orang lain atau suatu korporasi yang dapat merugikan keuangan negara atau perekonomian negara."

\section{B. Kenapa Korupsi}

Masalah korupsi selalu menarik untuk dibicarakan karena berbagai hal. Pertama, korupsi menyangkut uang rakyat atau harta negara yang harus digunakan sesuai kehendak rakyat atau peraturan perundang-undangan yang dibuat negara. Bila menyangkut uang atau kekayaan pribadi, maka itu adalah kejahatan biasa yang disebut

${ }^{2}$ CD-ROM Merriam-Webster English Dictionary, artikel corrupt.

${ }^{3}$ Hendry Campbell Black, Black's Law Dictionary (St. Paul, Minn.: West Publishing Co., $11^{\text {th }}$ reprint, 1997), hlm. 345 . 
pencurian, penipuan, perampokan dan lain-lain. Bila terbukti, maka kejahatan seperti ini dihukum dengan hukum biasa yang diatur dalam Kitab Undang-Undang Pidana biasa. Sementara itu, kejahatan korupsi adalah kejahatan luar biasa yang harus ditangani secara luar biasa, melalui pengadilan khusus, dengan hakim yang dilatih khusus. dan dengan hukuman yang lebih berat. Ini antara lain dibunyikan dalam pertimbangan UU No. 20 Tahun 2001 Tentang Perubahan UU No. 31 Tahun 1999 Tentang Pemberantasan Tindak Pidana Korupsi, bahwa "tindak pidana korupsi perlu digolongkan sebagai kejahatan yang pemberantasannya harus dilakukan secara luar biasa." Dalam penjelasannya antara lain dinyatakan bahwa "pemberantasan tindak pidana korupsi harus dilakukan dengan cara yang khusus. antara lain penerapan sistem pembuktian terbalik, yakni pembuktian yang dibebankan kepada terdakwa."

Kedua, korupsi adalah penyakit masyarakat yang akan menghancurkan sebuah negara bila tidak segera dibendung. Sebagai penyakit, maka penyelesaiannya tidak hanya dengan menghukum para pelakunya, tetapi terutama sekali adalah dengan menyembuhkan penyakit masyarakat yang menyebabkan tingkah laku korup. Setelah kejahatan korupsi ditumpas melalui penegakan hukum yang benar, maka tugas negara dan masyarakat selanjutnya adalah membina masyarakat melalui pendidikan formal, pendidikan masyarakat dan pendidikan rumah tangga. Membawa koruptor ke meja hijau adalah sebuah tugas berat, dan membina masyarakat anti koruspi merupakan tugas yang lebih berat lagi.

Ketiga, korupsi melibatkan orang-orang yang seharusnya menjadi panutan masyarakat karena mereka adalah tokoh yang dipilih dan terpilih, dari kalangan terpelajar dan bahkan berpengetahuan seperti ulama, disumpah menurut agama dan kepercayaannya sebelum memangku jabatan, dan lain-lain. Membiarkan korupsi merajalela akan melahirkan krisis kepercayaan, sikap putus asa, kehilangan kepemimpinan publik dan lain-lain sehingga negara akan mati secara perlahan-lahan. Selanjutnya akan berlaku apa yang disebut "the decline of civilization" oleh Arnold J. Toyenbee dalam A Study of History dan "peradaban tumbuh silih berganti" seperti yang diungkapkan oleh Ibnu Khaldun dalam al-Muqaddimah. 


\section{Kasus-Kasus Mutakhir}

Permasalahan korupsi dapat kita lihat dari dua sumber korupsi yang menarik perhatian publik akhir-akhir ini. Pertama adalah sekitar dana taktis Komisi Pemilihan Umum KPU), dan kedua adalah dana abadi ummat (DAU) di Departemen Agama.

Dana taktis tidak hanya ada di KPU. Dapat dikatakan bahwa hampir semua badan resmi negara dan kantor-kantor pemerintah mempunyai dana taktis dari sumber yang tidak sama. Dana taktis biasanya berasal dari sebuah kebijakan dari sebuah badan atau kantor yang sumber dan penggunaannya hanya diketahui oleh para pentinggi di badan atau kantor tersebut. Dari kasus-kasus korupsi KPU yang sedang diungkap sekarang, dana tersebut berasal dari rekanan KPU yang berhubungan dengan perlengkapan pemilu seperti pencetakan kartu suara, pembuatan kotak suara, pembelian tinta, jasa transportasi, pembelian alat-alat elektronik seperti komputer, telefon, telefon genggam, kendaraan dan lain-lain. Dana taktis dalam kasus KPU melibatkan make-up harga, kwitansi fiktif, tender fiktif, kolusi, sogokan kepada lembaga-lembaga terkait seperti DPR, KPK dan lain-lain.

Jadi pada kasus KPU, dana taktis berhubungan dengan pengadaan barang. Dengan demikian, salah satu pintu pengungkapan kasus korupsi dapat dimulai dari masalah pengadaan barang di badan-badan resmi dan kantor-kantor pemerintahan yang ada. Semua badan resmi dan kantor pemerintahan mempunyai proyek pengadaan barang-barang setiap tahun dari anggaran rutin dan anggaran pembangunan. Kasus pengadaan barang di KPU adalah korupsi baru yang umumnya dilakukan oleh orang-orang "yang belum berpengalaman" karena mereka bukan berasal dari dunia birokrat sehingga lebih mudah tersingkap. Kasus pengadaan barang di badan dan kantor lain mungkin lebih sulit terungkap karena dilakukan oleh birokrat yang sudah berpengalaman bertahaun-tahun dalam proyek pengadaan barang seperti ini sehingga kemungkinan kejahatan yang dilakukan lebih rapih.

Korupsi pada DAU berhubungan dengan kelebihan ongkos naik haji yang disetor oleh calon haji setiap tahun. Dari ONH yang ditetapkan pemerintah setiap orang haji dalam prakteknya tidak semuanya terpakai. Haji itu sendiri dalam istilah agama adalah "tijâratan lan tabura" (dagang yang tidak pernah rugi). Pada zaman Tarmizi Tahir menjadi Menteri Agama pernah terungkap oleh beliau bahwa sisa $\mathrm{ONH}$ tersebut sering mencapai 50 milyar rupiah. Di negara tetangga Malaysia, ONH diurus oleh badan yang disebut Tabung Haji. Sesuai namanya, dana tersebut adalah tabungan orang haji dan bila $\mathrm{ONH}$ yang real kurang dari yang mereka tabung, maka sisanya kembali kepada orang haji yang bersangkutan berupa investasi atas nama dirinya. Di zaman lampau, sebelum adanya PP tentang DAU, penggunaan 
dana orang haji Indonesia semuanya terserah kepada Menteri Agama dan Pemerintah. Konon kabarnya sisa dana haji sering pula digunakan untuk mendukung kebijakan Pemerintah, memenangkan Golkar dalam pemilu dan lain-lain. Selama itu tidak ada pertanggungjawaban penggunaannya kepada jama`ah haji Indonesia sebagai pemilik dana.

Haji sebagai ibadah agama mendapatkan pahala sorga di akhirat, tetapi sebagai bisnis yang menghasilkan uang kepada banyak orang di lingkungan Depag telah memberikan pahala dunia kepada orang-orang tertentu. Bila bisnis ini dilakukan secara legal dan halal, tentu juga akan mendapatkan pahala akhirat, tetapi belajar dari kasus KPU, susah dapat diyakini bahwa semuanya berjalan legal dan halal. Sebagai bisnis, haji melibatkan berbagai proyek pengadaan barang dan alat seperti alat transportasi, akomodasi, kosumsi/katering, seragam, pakaian ihram dan lain-lain. Bila pendekatan dana taktis dan pengadaan barang-barang di KPU juga diterapkan, maka bisa jadi akan tersingkat berbagai kasus make-up, kolusi, kwitansi fiktif, tender fiktif, manipulasi dan lain-lain. Ini tentu di samping penyalahgunaan DAU yang sekarang sedang diperiksa oleh pihak terkait dan sebagiannya telah ditetapkan sebagai tersangka dan dijatuhi vonis pengadilan.

Menarik dalam dua sumber korupsi ini karena keduanya melibatkan pejabat dan pegawai pemerintah yang menjadi harapan rakyat. Pada kasus KPU terdapat aktivis LSM dan kaum akademisi yang sebelumnya tidak pernah dipertanyakan integritas kepribadian mereka. Pada kasus DAU adalah pejabat dan pegawai pemerintah yang menangani masalah agama yang dulu pada masa Meneri Agama Mukti Ali disebut sebagai teknograt langit. Ibarat langit yang melindungi bumi dan memberi rezki dan kesegaran kepada seluruh penduduk, maka para pejabat dan pegawai negeri di departemen ini sebenarnya diharapkan rakyat akan menjadi suluh masyarakat dalam penegakan ma'ruf dan pencegahan kemungkaran. Dengan kasus DAU, maka harapan tersebut menjadi pudar di mata masyarakat.

Dari dua sumber korupsi ini, dapat diambil kesimpulan bahwa integritas ilmiah dan pengetahuan agama serta mengurus urusan agama saja tidak cukup untuk mencegah korupsi.

\section{Jalan Keluar}

Dalam ilmu politik dikatakan bahwa kekuasaan yang tidak terbatas cenderung melakukan korupsi. Masyarakat meyakini bahwa korupsi sudah merupakan bagian dari romantika kekuasaan sejak lama di Indonesia, tetapi karena pada masa Orde Lama dan Orde Baru demokrasi tidak berjalan sebagaimana mestinya, maka jarang sekali kasus-kasus korupsi yang muncul 
ke permukaan. Era Reformasi memberikan harapan besar kepada rakyat untuk sebuah pemerintahan yang bersih dari kolusi, korupsi dan nepotisme. Alhamdulillah, dalam masa pemerintahan yang sekarang ini sudah dimulai penyingkapan kasus-kasus korupsi. Sungguhpun demikian, masih menjadi pertanyaan masyarakat, apakah usaha ini akan berjalan terus atau akan berhenti di tengah jalan, atau bersifat pilih kasih dengan menindak pihakpihak tertentu saja dan membiarkan pihak-pihak tertentu pula.

Penegakan hukum adalah jalan keluar yang dapat diusulkan untuk pemberantasan korupsi di Indonesia. Asas yang utama dalam hukum adalah reward and punishment dengan pengertian orang yang menaati hukum harus dihargai dan orang yang melanggar hukum harus dihukum. Di luar itu berlaku asas praduga tak bersalah, bahwa seseorang tetap dipandang tidak bersalah selama tidak terbukti melalui pengadilan yang bebas dan adil bahwa ia tidak bersalah.

Selain itu, menurut hemat penulis, perlu pengawasan masyarakat terhadap pejabat dan pegawai pemerintah dan pendidikan ketaqwaan yang dapat membentengi masyarakat dari perbuatan melawan norma moral dan norma hukum.

\section{Pengawasan Masyarakat ${ }^{t}$}

Dalam kehidupan berbangsa dan bernegara kita, akhir-akhir ini banyak pihak yang merasakan lemahnya segi pengawasan terhadap lembagalembaga publik. Banyak aset negara dan sumber daya alami dan manusiawi yang sering tersia-sia karena lemahnya fungsi pengawasan. Sebagian masyarakat bahkan sering mengeluhkan bahwa lembaga seperti kepolisian dan sekolah yang seharusnya menjadi pengawas keamanan masyarakat dan anak didik, malah masih perlu diawasi, ibarat pagar makan tanaman.

Dalam sebuah negara, kita mengenal tiga lembaga legislatif, eksekutif dan yudikatif, yang terkenal dengan nama Trias Politika. Secara teoritis, ketiga lembaga tersebut diawasi oleh rakyat sebagai pemegang kekuasaan tertinggi dalam negara, tetapi dalam prakteknya, mekanisme pengawasan oleh rakyat tersebut sering tidak berjalan dengan baik. Penyebabnya antara lain karena kurangnya kesadaran masyarakat secara umum tentang peran mereka sebagai pengawas aparat negara dan kecenderungan sebagian orang yang hanya mementingkan keselamatan diri sendiri.

${ }^{4}$ Rifyal Ka'bah. "Pengawasan Masyarakat". Buletin Dakwah, No. 08 Thn XXXII. 25 Februari 2005 
Secara teoritis juga, lembaga eksekutif atau pemerintah diawasi oleh lembaga legislatif atau DPR, dan lembaga yudikatif (pengadilan) diawasi oleh Komisi Yudisial yang sudah terbentuk. Pertanyaan yang timbul sekarang, lalu siapa yang mengawasi lembaga legislatif? Pertanyaan ini menjadi penting mengingat belakangan ini sebagian anggota DPR mendapat sorotan masyarakat karena tindakan melanggar norma-norma masyarakat dan/atau norma-norma hukum yang mereka lakukan. Pimpinan dan/atau anggota DPR di berbagai daerah, misalnya, bahkan menjadi terdakwa dalam perkara pidana korupsi dan sebagiannya sedang menjalani hukuman. Sampai sekarang masih belum terpikirkan lembaga yang akan mengawasi DPR dan bila lembaga pengawas wakil-wakil rakyat ini terwujud, maka akan muncul permasalahan khusus bahwa DPR sebagai perwakilan rakyat masih memerlukan pengawasan rakyat. Karena itu, perlu dipikirkan bentuk-bentuk pengawasan baru yang tidak hanya mengawasi para anggota DPR dan aparat negara, tetapi sekaligus mengawasi setiap individu dalam masyarakat.

Dalam sosiologi dikenal dua bentuk pengawasan masyarakat (social control). ${ }^{5}$ Pertama adalah melalui internalisasi norma-norma yang dipegang teguh masyarakat. Kedua adalah melalui penggunakan sanksi terhadap tingkah langku yang menyimpang (deviation) dari norma-norma tersebut, baik sanksi moral, misalnya dengan pengucilan oleh masyarakat, maupun sanksi penghukuman melalui peraturan perundang-undangan atau penghargaan untuk anggota masyarakat yang berjalan sesuai norma-norma.

Tuntunan Islam dari Qur'an dan Sunnah sebenarnya adalah normanorma yang dapat mengawasi tingkah laku masyarakat bila dapat ditanamkan melalui pendidikan dan pembiasaan. Internalisasi norma-norma ini dapat dilakukan melalui prinsip amar ma'ruf nahi mungkar dengan kewajiban setiap orang dalam masyarakat untuk menggalakkan perbuatan baik dan mencegah perbuatan mungkar. Sungguhpun demikian, pendidikan dan pembiasaan semata tidak menjamin anggota masyarakat berperilaku baik sesuai norma-norma Qur'an dan Sunnah. Hal itu karena dari waktu ke waktu selalu muncul individu-individu dan kelompok-kelompok yang menyimpang dari tingkah laku terpuji. Karena itu, diperlukan tindakan reward and punishment melalui lembaga-lembaga masyarakat, baik lembaga sosial seperti masyarakat adat, organisasi sosial, LSM, maupun lembaga negara. Dengan tindakan penghargaan dan penghukuman ini, masyarakat dapat diarahkan kepada tingkah laku yang benar.

${ }^{5}$ Philip Nicholls and Alan Sillitoe (eds.), Collins Dictonary of Sociology (Glasgow: Harper Collins Publisher, 1995), hlm. 606. 
Internalisasi norma-norma terlebih dahulu memerlukan pemahaman yang benar terhadap tuntunan Qur'an dan Sunnah. Ini berarti pembentukan kader dan ilnuwan dengan wawasan mendalam mengenai Islam dalam semua disiplin ilmu dan mempunyai komitmen kuat untuk menerapkannya dalam kehidupan pribadi, rumah tangga dan masyarakat. Mereka inilah yang menjadi matahari penyinar masyarakat dalam upaya internalisasi normanorma. Pengetahuan yang benar tentang Islam akan mendukung internalisasi norma-normanya dalam kehidupan masyarakat. is

Internalisasi norma-norma adalah satü cara yang efektif dalam mengawas tingkah laku individu, pertama karena tabiat semua norma moral secara umum yang mengendalikan hati nurani orang-perorang, dan kedua karena sifat ilahiyah norma-norma Islam yang berdasarkan keyakinan bahwa tingkah laku makhluk manusia tanpa kecuali mendapat pengawasan langsung dari Allah s.w.t. Nilai-nilai Islam mengajarkan bahwa perbuatan baik akan dibalasi dengan baik dan perbuatan jahat akan dibalasi dengan jahat, baik dalam kehidupan dunia maupun dalam kehidupan yang akan datang di akhirat. Sidi Gazalba, salah seorang intelektual muslim menyatakan dalam tulisan-tulisannya pada tahun enampuluhan dan tujuhpuluhan, bahwa keyakinan akan adanya hari akhirat membuat kita, suka atau tidak suka, harus taat kepada norma-norma Islam.

Seperti disinggung di atas, inernalisasi norma-norma Islam harus diikuti dengan tindakan disipliner bagi para pelanggar batas sehingga menjadi pelajaran bagi warga masyarakat yang lain bahwa mereka tidak boleh mempermainkan norma-norma dan bila itu dilakukan, maka mereka akan mendapat ganjaran dari masyarakat dan negara. Jadi, mekanisme pengawasan masyarakat yang paling efektif setelah internalisasi normanorma adalah supremasi hukum dengan pengertian, siapa saja yang melanggar hukum akan ditindak dengan tegas. Segi ini pulalah yang dirasakan kurang pada waktu ini dalam kehidupan berbangsa dan bernegara kita.

Dengan demikian, norma-norma agama harus menjadi norma-norma hukum yang ditegakkan bersama oleh masyarakat dan negara. Dengan kata lain, orang-orang yang duduk di lembaga legislatif, eksekutif dan yudikatif mestilah orang-orang yang memahami norma-norma Islam dalam bidang yang mereka geluti dan merasakan pentingnya inernalisasi norma-norma tersebut dalam mengawasi tindak tanduk mereka di depan atau di belakang publik. Untuk lebih efektifnya pengawasan tersebut, berbagai norma agama tersebut perlu menjadi norma hukum yang mempunyai kekuatan mengikat kepada semua orang. Perjalanan ini masih panjang, yang memasuki berbagai bidang yang sangat luas, mulai dari pendidikan rumah tangga dan sekolah, sampai kepada pendidikan politik, masyarakat dan orang dewasa. 
Sungguhpun demikian, tidak ada perjalanan yang terlalu panjang untuk suatu cita-cita dan sebuah bangsa yang besar. Perjalanan beribu-ribu mil selalu dimulai dari langkah pertama.

\section{Pendidikan Ketaqwaan ${ }^{6}$}

Bertaqwa kepada Tuhan Yang Maha Esa selalu merupakan salah satu syarat yang ditetapkan oleh undang-undang negara di Indonesia untuk menjadi pejabat negara, pejabat tinggi atau pegawai negeri biasa, baik sipil maupun militer. Secara formal dapat dikatakan bahwa tidak ada pejabat yang dapat diangkat sebagai pejabat bila tidak memenuhi syarat taqwa.

Ini, misalnya, dapat dilihat dari UU No. 23/2003 tentang Pemilihan Umum Presiden dan Wakil Presiden (Pasal 6a); UU No. 12/2003 tentang Pemilihan Umum Anggota DPR, DPD, dan DPRD (Pasal 60b); UU No. /2004 tentang Mahkamah Agung (Pasal 7b); UU No. 2004 tentang Kejaksaan; UU No. 2004 tentang Kepolisian Negara (Pasal 2b) dan lain-lain.

Penjelasan berbagai undang-undang di atas menyatakan bahwa: "Yang dimaksud dengan bertaqwa kepada Tuhan Yang Maha Esa adalah dalam arti taat menjalankan kewajiban agamanya."

Dapat dipahami dari penjelasan ini bahwa pejabat negara yang tidak menjalankan kewajiban agama yang ia anut tidak cukup syarat untuk pejabat negara.

Memperhatikan sejarah perundang-undangan Indonesia, dapat dipastikan bahwa kata taqwa masuk ke dalam bahasa perundang-undangan pada awal pemerintahan Orde Baru setelah kegagalan kaum komunis dalam perebutan kekuasaan berdarah pada tanggal 1 Oktober 1965. Begitu khawatirnya pembuat undang-undang Indonesia pada waktu itu terhadap bahaya ajaran komunisme atheisme yang anti agama bagi keselamatan bangsa di masa di depan, maka setiap pejabat dan setiap warga negara diharuskan memiliki sifat taqwa kepada Tuhan Yang Maha Esa. Taqwa secara bahasa antara lain berarti "takut" dan "mawas diri". Seorang yang bertaqwa akan selalu menjaga dirinya dari segala perbuatan yang dilarang Tuhan. Sikap mawas diri tersebut merupakan pancaran rasa takutnya kepada Tuhan Yang Maha Esa.

Sungguhpun demikiran, dari berbagai tingkah laku tidak terpuji berbagai pejabat negara yang dilaporkan oleh media massa, terutama akhir-

${ }^{6}$ Rifyal Ka'bah, "Pejabat Yang Bertaqwa", Buletin Dakwah, No. 18 Thn. XXXII, 06 Mei 2005. 
akhir ini, sebenarnya banyak para pejabat negara yang tidak memahami kata itu, atau kalaupun memahaminya, tetapi telah melanggarnya dengan sengaja karena ketiadaan takut kepada Tuhan Yang Maha Esa.

Pengertian taqwa kepada Tuhan Yang Maha Esa adalah dalam konteks ajaran Islam dan tidak mungkin dalam konteks agama lain. Pemahaman seperti ini juga pernah ditegaskan oleh beberapa orang penandatangan Piagam Jakarta dari kalangan ulama. Piagam Jakarta tidak lain adalah Pembukaan UUD 1945 tanpa tujuh kata yang kemudian dihilangkan tanpa alasan yang jelas. Tuhan Yang Maha Esa adalah inti kalimat tauhid bahwa tidak ada Tuhan yang patut disembah dan diperhatikan suruhan serta larangan-Nya kecuali Allah Yang Esa, yang tidak pernah menjadi anak atau beranak.

Taqwa berasal dari bahasa Arab dan menjadi salah satu istilah alQur'an. Banyak penjelasan tentang pengertian taqwa dalam al-Qur'an dan as-Sunnah. Sebagai contoh, dalam ayat nomor 2 surah al-Baqarah, orang bertaqwa dijelaskan dalam ayat 3,4 dan 5 .

Dalam ayat-ayat ini, paling tidak ada lima ciri orang bertaqwa. Pertama adalah beriman atau meyakini soal-soal ghaib dalam agama seperti surga, neraka, malakat, jin, iblis, alam kubur, dan lain-lain. Kedua adalah mengerjakan shalat, terutama shalat wajib lima waktu dan shalat Jum'at bagi kaum pria. Ketiga adalah menggunakan rezki pemberian Allah menurut yang la kehendaki. Misalnya adalah penggunaannya untuk keperluan zakat, sedekah, sumbangan, pembiayaan keluarga dan lain-lain. Keempat adalah meyakini wahyu yang diturunkan kepada Nabi Muhammad dan nabi-nabi berdahulu sebagai wahyu Allah. Kelima adalah keyakinan akan adanya hari akhirat.

Sebagai contoh, dari ciri orang bertaqwa nomor dua, yakni melaksanakan shalat. Kita mendengar dan mengetahui banyak pejabat beragama Islam yang tidak shalat. Malah konon kabarnya seorang Presiden yang ahli agama di masa lalu tidak melakukan shalat-shalat wajib secara teratur. Memang pada waktu ini cukup banyak para pejabat kita yang terlihat melakukan shalat di tempat-tempat peribadatan umum, tetapi jumlah yang tidak shalat juga cukup banyak. Ini, misalnya, dapat kita lihat di kota-kota besar Indonesia di mana banyak pejabat muslim yang masih tetap berada di kantor pemerintah atau berkeliaran dengan mobil di luar kantor pada setiap hari Jum'at.

Contoh lain adalah ciri nomor empat, yaitu keyakinan terhadap wahyu yang diturunkan kepada Nabi Muhammad dan nabi-nabi terdahulu seperti tercantum dalam salah satu rukun iman. Hari ini banyak orang muslim yang mempertanyakan kebenaran al-Qur'an sebagai wahyu langsung dari Allah kepada Nabi Muhammad dan kebenaran as-Sunnah sebagai wahyu tidak 
langsung kepada Mabi Muhammad. Mereka antara lain mempertanyakan ayat-ayat dan Hadits-hadits tentang waris, perbedaan alami antara pria dan wanita, perbedaan anak kandung dan anak angkat, kebolehan pria beristeri lebih dari satu bila memenuhi syarat dan lain-lain. Malah ada orang-orang tertentu yang berani mengawinkan wanita muslimah dengan orang Katolik, Protestan dan lain-lain. Anehnya, orang-orang yang mempertanyakan atau meragukan ayat al-Qur'an ini sebagiannya merupakan almuni Fakultas Ushuluddin atau Fakultas Syari'ah dan sekaligus juga pejabat negara atau paling tidak pegawai tinggi atau rendah Departemen Agama. Sementara itu mereka selalu memcaca dalam ayat 2 surah al-Baqarah atau paling tidak pernah dulunya membaca bahwa "Kitab (al-Qur'an) ini, tidak terdapat keraguan di dalamnya, merupakan petunjuk bagi orang-orang yang bertaqwa".

Ciri orang bertaqwa kelima adalah yakin terhadap hari akhirat. Seperti diterangkan oleh almarhum Prof. al-Faruqi, kata yakin mempunyai pengertian yang sama dengan kata iman, yang diterima dengan kepuasan hati dan pikiran. Hari Akhirat, yaitu hari lain dari hari dunia ini, disebut juga Hari Agama (yaum ad-dîn) dan Hari Perhitungan (yawm al-hisab). Semuanya diartikan sebagai Hari Pembalasan (yawm al-jazâa') di mana perbuatan jahat selama hidup di dunia akan dibalasi dengan balasan jahat dan perbutan baik akan dibalasi dengan balasan baik. Ini adalah semacam konsep rewards and punishment dalam dunia pendidikan dan dunia hukum.

Dalam kaitan dengan ciri kelima ini, kita melihat banyak orang dalam kehidupan dunia ini, baik pejabat maupun bukan, yang tidak takut melakukan pelanggaran dan kejahatan. Mereka tidak hanya melanggar hukum buatan manusia, tetapi juga hukum yang berasal dari syari'at Allah S.W.T.

\section{Penutup}

Banyak penyebab tindak pidana korupsi, antara lain adalah sebagai berikut:

Pertama, minimnya gaji pejabat negara dan pegawai negeri secara umum dibanding kebutuhan hidup mereka sehingga mendorong pihak-pihak yang lemah iman untuk menyalahgunakan kekuasaan.

Kedua, jiwa konsumerisme yang semakin meningkat dalam masyarakat Indonesia sejak zaman Orde Baru, terutama akibat periklanan massal, dunia kosmetik dan hiburan, membuat sebagian orang tertarik kepada barang-barang yang tidak mungkin mereka beli dari pendapatan rutin. 
Ketiga, lemahnya pengawasan masyarakat, baik melalui lembaga resmi pengawasan, maupun media penyalur pendapat umum, seperti surat kabar, majalah, radio, televisi, khutbah, rapat umum dan lain-lain.

Keempat, rekruitmen pejabat negara dan pegawai negeri yang kurang memperhatikan integritas pribadi dan ketaqwaan kepada Tuhan Yang Maha Esa.

Kelima, lemahnya penegakan hukum secara umum di mana orang bersalah tidak mendapat hukuman dan pencari keadilan susah mendapatkan keadilan yang tidak memihak. 


\section{Daftar Pustaka}

CD-ROM Merriam-Webster English Dictionary, Artikel Corrupt.

Hendry Campbell Black, Black's Law Dictionary (St. Paul, Minn.: West Publishing Co., $11^{\text {th }}$ reprint, 1997).

Rifyal Ka'bah, "Pengawasan Masyarakat", Buletin Dakwah. No. 08 Thn XXXII, 25 Februari 2005.

, "Pejabat Yang Bertaqwa", Buletin Dakwah, No. 18 Thn. XXXII, 06 Mei 2005.

Philip Nicholls and Alan Sillitoe (eds.), Collins Dictonary of Sociology (Glasgow: Harper Collins Publisher, 1995). 